\title{
Antitumor activity of biflavonoids from O uratea and Luxemburgia on human cancer cell lines
}

\author{
J uliana Feijó de Souza Daniel, Cassia Cristina Fernandes Alves, Ivana Grivicich*^, Adriana Brondani da \\ Rocha*^, Mário Geraldo de Carvalho
}

Departamento de Q uímica, Instituto de Ciências Exatas, U niversidade Federal Rural do Rio de Janeiro, Seropédica, RJ, *Laboratório de Marcadores de Estresse Celular, Centro de Pesquisas em Ciências Médicas, U niversidade Luterana do Brasil, Canoas-RS, ^Programa de Pós-Graduação em Diagnóstico Genético e Molecular, Universidade Luterana do Brasil, Canoas-RS, Brasil

Received: 26.01.2007

Revised: 25.05.2007

Accepted: 27.08 .2007

Correspondence to: Mário G. de Carvalho E-mail: mgeraldo@ufrrj.br

\section{ABSTRACT}

The biflavones 7,7"-dimethyllanaraflavone (1), agathisflavone (2), and 7"methylagathisflavone (3) isolated from the leaves of $O$ uratea hexasperma and luxenchalcone (4) isolated from the leaves and branches of Luxemburgia octandra, as well as a mixture of 7,7"-dimethyllanaraflavone and 7"-methylagathisflavone, were assayed against HT-29 colon adenocarcinoma, $\mathrm{N} \mathrm{Cl-H} 460$ non-small cell lung carcinoma, M CF-7 breast cancer cell, OVCAR-3 ovarian adenocarcinoma cells, and RXF-393 renal cell carcinoma. The results show significant activities, particularly for 7,7"-dimethyllanaraflavone $\left(\mathrm{IC}_{50} 0.77\right.$ $\pm 0.08,2.42 \pm 0.22$, and $2.59 \pm 0.32 \mu \mathrm{g} / \mathrm{ml}$ for NCl-H 460, MCF-7, and OVCAR-3, respectively), and for $7 "$-methylagathisflavone $\left(\mathrm{IC}_{50}\right.$ values of $\left.4 \mu \mathrm{g} / \mathrm{ml}\right)$. Luxenchalcone revealed significant cytotoxicity on the five cell lines tested.

KEY WORDS: Antitumor agents, cancer cell lines, biflavonoids, Luxemburgia, O uratea

Anticancer agents may be derived from nature through isolation of active lead compounds..$^{11,2]}$ There are examples of successful drugs obtained from plant sources which have had a profound impact in the field of cancer. Indeed, the medical armamentarium is rich in examples of important agents that were isolated from plants and which continue to be used in current, routine clinical practice. Worldwide efforts are on to discover new anticancer agents from plants. ${ }^{\mid 3-5]}$

The Ochnaceae is a large family of tropical plants, with 40 genera, from which 600 species have been identified in South America. In the course of our phytochemical and pharmacological investigations on Brazilian plants, we have studied species of both Ouratea and Luxemburgia genera in which the presence of biflavonoids ${ }^{[6-12]}$ were detected. Biflavonoids from Ouratea have been found to possess cytotoxic and antitumor activities ${ }^{[13]}$ as well as the ability to inhibit DNA topoisomerases. ${ }^{[14,15]}$ Natural and synthetic flavonoids have been shown to have antileukemic activity in P388-infected mice. ${ }^{[16]}$ Moreover, a 5,3'-dihydroxy-3-6,7,8,4'-pentamethoxyflavone isolated from Polanisia dodecandra demonstrated remarkable cytotoxicity and inhibition of tubulin polymerization against a panel of human tumor cell lines. ${ }^{[17]}$ The biflavonoids have advantages over simple monomeric flavonoids, such as the ability to survive first-pass metabolism, which inactivates most flavonoids. ${ }^{[18]}$

We have earlier reported the isolation and the structure determination of four biflavonoids: 7,7"-dimethyllanaraflavone, agathisflavone, and 7"-methylagathisflavone from Ouratea hexasperma (leaves) and luxenchalcone from Luxemburgia octandra (leaves and branches). ${ }^{[6,7]}$ In the present study we investigated the antiproliferative activity of these compounds against five human cancer cell lines (HT-29, NCI-H460, RXF-393, MCF-7, and OVCAR-3).

\section{Materials and Methods}

\section{Plant material}

The leaves of Ouratea hexasperma St.-Hill (Ochnaceae) were collected at João Pessoa, PB, Brazil, in October 2002. A voucher specimen (JPB-21438) was deposited at the herbarium of Universidade Federal da Paraíba, João Pessoa-PB, Brazil. The leaves and branches of Luxemburgia octandra St. Hill were collected at Morro de São Sebastião, Ouro Preto-MG, Brazil. 
A voucher specimen (26197) was deposited at the herbarium, OUPR-UFOP, Instituto de Ciências Exatas e Biológicas, Universidade Federal de Ouro Preto-MG, Brazil.

\section{Extraction and isolation}

Air-dried leaves of 0 . hexasperma (585.0 g) were extracted exhaustively with dichloromethane and methanol. The solvents were removed under vacuum to yield the extracts residues LeavesDichloromethane (LD, $14.5 \mathrm{~g}$ ) and Leaves-Methanol (LM, $133.0 \mathrm{~g}$ ). The LD residue (13.5 g) was filtered on a silica gel column, and the fraction eluted with ethyl acetate was crystallized from $\mathrm{MeOH}$ to afford 7,7"-dimethyllanaraflavone (1). The methanolic extract (LM) was partitioned with organic solvents. The hexane:diethyl ether 1:1 (named OFMHE-6) fraction was filtered on a sephadex LH-20 column, to give 7,7"-dimethyllanaraflavone (1) and 7"methylagathisflavone (3). ${ }^{|6|}$ Dried leaves (621.0 g) and branches $(1.8 \mathrm{Kg})$ of L. octandra were powdered and extracted with hexane and ethyl acetate. The solutions were concentrated under vacuum distillation and after removal of the remaining solvent, yielded the residues A $(6.1 \mathrm{~g})$ and B (10.4 g) from the leaves and C (4.8 g) and D (20.7 g) from the branches, respectively, with hexane and ethyl acetate. The residue D was dissolved in $\mathrm{H}_{2} \mathrm{O} / \mathrm{CH}_{3} \mathrm{OH}$ (1:1) and extracted with hexane/diethyl ether (1:1) and this fraction (D-1, $3.5 \mathrm{~g}$ ) was filtered on a sephadex LH-20 column using methanol as the mobile phase. Some fractions yielded solid material that were crystallized from acetone/ethyl acetate to yield pure luxenchalcone (4). ${ }^{.7]}$

\section{Tumor cell line maintenance}

The five cell lines HT-29 human colon adenocarcinoma, NCI-H460 human non-small cell lung carcinoma, RXF-393 human renal cell carcinoma, MCF-7 human breast cancer, and OVCAR-3 human ovarian adenocarcinoma were obtained from American Type Culture Collection (Rockville, MD, USA). All the cell lines were maintained in RPMI 1640 culture medium supplemented with $10 \%$ fetal bovine serum at $37^{\circ} \mathrm{C}$ and in a humidified atmosphere of $5 \% \mathrm{CO}_{2}$ in air.

\section{Cell growth inhibition studies}

For the assay of antiproliferative activity, the biflavonoids (1-4) and the fraction with the mixture of the biflavonoids $1+3$ (OFMHE-6) were dissolved in dimethylsulfoxide (DMSO) and further diluted in cell culture medium to obtain a final DMSO concentration of $0.25 \%(\mathrm{v} / \mathrm{v})$. The cell lines were inoculated into 96-well microplates. After $24 \mathrm{~h}$, triplicate cultures were treated for $72 \mathrm{~h}$ with the biflavones in final volumes of $200 \mu \mathrm{l}$ per well. Untreated control wells received only maintenance medium. The antineoplastic agent etoposide was used as a positive control.

Cellular responses were colorimetrically assessed by sulforhodamine B (SRB) assay. ${ }^{[19]}$ Briefly, the cells were fixed with $50 \%(\mathrm{w} / \mathrm{v} ; 50 \mu \mathrm{l} /$ well) trichloroacetic acid and stained with $0.4 \%$ SRB. Later the cell-bound SRB was solubilized by the addition of $10 \mathrm{mM}$ Trizma base. The latter was colorimetrically assessed with an ELISA microplate reader (Multiskan Ex, Labsystems, Finland) at a wavelength of $540 \mathrm{~nm}$.

Cell growth inhibition was expressed in terms of percentage of untreated control absorbance following subtraction of the mean background absorbance. Compounds were considered to have potent growth inhibitory activity when the reduction in SRB absorbance was more than $25 \%$ compared to untreated control cells. ${ }^{|20|} \mathrm{The}_{\mathrm{IC}} \mathrm{C}_{50}$ concentration (50\% inhibition of cell growth values) was calculated from the dose-response curves.

\section{Statistics}

All the experiments were conducted in triplicate. The differences in means were analyzed by one-way ANOVA followed by Tukey's test. $P<0.05$ was taken to indicate statistical significance.

\section{Results}

The tested biflavones showed different patterns of growth inhibitory activity ( $<25 \%$ of control cell growth) among the cell lines tested [Table 1]. The 7,7"-dimethyllanaraflavone (1) promoted growth inhibitory activity at $3-5 \mu \mathrm{g} / \mathrm{ml}(<25 \%$ control growth) in NCI-H460, MCF-7, and OVCAR-3 cell lines [Table 1]. This significant effect was also confirmed by the low values of $\mathrm{IC}_{50}$ for these cell lines $(0.77-2.5 \mu \mathrm{g} / \mathrm{ml})$ [Table 1]. However, in HT-29 and RXF-393 cell lines this compound induced comparatively low cytotoxic effect [Table 1].

The 7"-methylagathisflavone (3) showed the highest activity on all cell lines, taking into account that the $\mathrm{IC}_{50}$ value was around $4 \mu \mathrm{g} / \mathrm{ml}$ for all the five cell lines tested [Table 1].

\section{Table 1}

Cytotoxic effect of the biflavonoids and etoposide in HT-29 colon adenocarcinoma, NCI-H460 non-small cell lung carcinoma, RXF-393 renal cell carcinoma, MCF-7 breast cancer, and OVCAR-3 ovarian adenocarcinoma. $\mathrm{IC}_{50}$ values are expressed as $\mu \mathrm{g} / \mathrm{mL}(\mathrm{mean} \pm \mathrm{SD}, \mathrm{n}$ $\geq 3$ )

\begin{tabular}{|c|c|c|c|c|c|}
\hline & HT-29 & $\mathrm{NCl}-\mathrm{H} 460$ & $R X F-393$ & MCF-7 & OVCAR-3 \\
\hline 7,7"-dimethyllanaraflavone (1) & $>50^{\mathrm{b}, \mathrm{c}, \mathrm{e}}$ & $0.77 \pm 0.08^{\mathrm{b}, \mathrm{c}, \mathrm{d}, \mathrm{e}}$ & $40.61 \pm 1.44^{\mathrm{b}, \mathrm{c}, \mathrm{e}}$ & $2.42 \pm 0.22^{b, c, d, e}$ & $2.59 \pm 0.32^{\mathrm{b}, \mathrm{c}, \mathrm{d}, \mathrm{e}}$ \\
\hline Agathisflavone (2) & $>50^{\mathrm{b}, \mathrm{c}, \mathrm{e}}$ & $>50^{\mathrm{a}, \mathrm{b}, \mathrm{c}, \mathrm{e}}$ & $44.89 \pm 1.84^{\mathrm{b}, \mathrm{c}, \mathrm{e}}$ & $>50^{\mathrm{a}, \mathrm{b}, \mathrm{c}, \mathrm{e}}$ & $>50^{\mathrm{a}, \mathrm{b}, \mathrm{c}, \mathrm{e}}$ \\
\hline 7"-methylagathisflavone (3) & $3.38 \pm 0.42^{\mathrm{a}, \mathrm{c}, \mathrm{d}, \mathrm{e}}$ & $4.36 \pm 0.35^{\mathrm{a}, \mathrm{d}, \mathrm{e}}$ & $3.86 \pm 0.64^{\mathrm{a}, \mathrm{c}, \mathrm{d}, \mathrm{d}, \mathrm{e}}$ & $4.58 \pm 0.22^{\mathrm{a}, \mathrm{c}, \mathrm{d}, \mathrm{e}}$ & $4.18 \pm 0.82^{\mathrm{a}, \mathrm{d}, \mathrm{e}}$ \\
\hline Luxenchalcone (4) & $12.01 \pm 1.59^{\mathrm{a}, \mathrm{b}, \mathrm{d}}$ & $6.85 \pm 0.73^{\mathrm{a}, \mathrm{b}, \mathrm{d}, \mathrm{e}}$ & $6.46 \pm 0.72^{\mathrm{a}, \mathrm{b}, \mathrm{d}}$ & $7.76 \pm 0.47^{\mathrm{a}, \mathrm{b}, \mathrm{d}}$ & $6.43 \pm 1.24^{\mathrm{a}, \mathrm{d}, \mathrm{e}}$ \\
\hline OFMHE-6 & $8.19 \pm 1.19^{a, b, d}$ & $9.88 \pm 1.57^{\mathrm{a}, \mathrm{b}, \mathrm{c}, \mathrm{d}}$ & $8.39 \pm 1.48^{a, b, d}$ & $9.02 \pm 1.20^{a, b, d}$ & $10.45 \pm 2.56^{a, b, c, d}$ \\
\hline Etoposide & $1.22 \pm 0.09^{\mathrm{a}, \mathrm{c}, \mathrm{d}, \mathrm{e}}$ & $0.27 \pm 0.02^{\mathrm{b}, \mathrm{c}, \mathrm{d}, \mathrm{e}}$ & $13.77 \pm 2.67^{\mathrm{a}, \mathrm{b}, \mathrm{c}, \mathrm{d}, \mathrm{de}}$ & $3.42 \pm 1.0^{\mathrm{c}, \mathrm{d}, \mathrm{e}}$ & $9.42 \pm 1.62^{\mathrm{a}, \mathrm{b}, \mathrm{d}}$ \\
\hline \multicolumn{6}{|l|}{ One-way ANOVA } \\
\hline $\mathrm{F}$ & 1800.7 & 1324.4 & 513.99 & 1318.0 & 520.58 \\
\hline df & 5 & 5 & 5 & 5 & 5 \\
\hline$P$ & 0.0079 & $<0.0001$ & 0.2409 & 0.0061 & 0.0862 \\
\hline
\end{tabular}

aDifferent from 7,7"-dimethyllanaraflavone; 'Different from 7"-methylagathisflavone; 'Different from Luxenchalcone; 'Different from Agathisflavone; 'Different from OFMHE-6 
Luxenchalcone (4), showed similar $\mathrm{IC}_{50}$ values on NCI-H460, RXF-393, MCF-7, and OVCAR-3 cell lines [Table 1]. On the other hand, in HT-29 cells, the $\mathrm{IC}_{50}$ increased by 1.7 fold compared to that of other cell lines.

Agathisflavone (2) did not have a major impact on the cell growth in any of the cell lines tested [Table 1].

Considering the better antitumor activity $(\mathrm{P}<0.05)$ observed with 7,7"-dimethyllanaraflavone and 7"-methylagathisflavone than other biflavones, we decided to test the effect of the mixture (OFMHE-6) of those compounds. The OFMHE-6 showed growth inhibitory activity ( $<25 \%$ of control cell growth) among the cell lines tested at $18-20 \mu \mathrm{g} / \mathrm{ml}$ and the $\mathrm{IC}_{50}$ values ranged from $8-10 \mu \mathrm{g} / \mathrm{ml}$ [Table 1].

\section{Discussion}

In order to evaluate the cytotoxic activity of four biflavonoids, antiproliferative assay with five human cancer cell lines were performed. As observed with the anticancer agent etoposide, the biflavonoids demonstrated different patterns of growth inhibition among the cell lines tested.

Our results indicate that 7,7"-dimethyllanaraflavone (1) had more selective activity among the cell lines tested. HT-29 and RXF-393 cell lines seem to be resistant, while NCI-H460 was the most sensitive cell line for this biflavone. The results are similar to a previous report of concentration-dependent growth inhibitory activity of another biflavonoid $\left(4^{\prime}, 5,7-\right.$ trihydroxyflavone $\left(3^{\prime} \rightarrow 0 \rightarrow 4^{\prime \prime \prime \prime}\right)-5^{\prime \prime}, 7^{\prime \prime}$-dihydroxyflavone) isolated from Luxemburgia octandra on murine Ehrlich carcinoma cells but not on human K562 leukemia cells. ${ }^{[14,15]}$

The significant growth inhibition induced by $7 "$ methylagathisflavone (3) on all the cell lines tested is in agreement with the observed antiproliferative activity of this biflavonoid against human K562 leukemia cells. ${ }^{[14]}$

The effect demonstrated with 7,7"-dimethyllanaraflavone, 7"-methylagathisflavone, and OFMHE-6 (a mixture of 7,7"dimethyllanaraflavone and 7 "-methylagathisflavone) could be explained by the presence of a methoxy group in carbon 7 . This group confers more lipophilicity to the substance, allowing better incorporation of these molecules into the cells. ${ }^{[20]}$ In contrast, agathisflavone does not have a methoxy group. This could probably explain the absence of antiproliferative activity with this compound.

The antitumor activity observed with luxenchalcone (4) is in accordance with several studies demonstrating that chalcones are cytotoxic in different tumor cell lines. ${ }^{[21-23]}$

Our findings suggest that, although the three biflavonoids demonstrated cytotoxicity on the five cell lines tested, the antiproliferative effect appears to vary depending upon tumor cell type; this should be further investigated to study the mechanism apart from possible toxicity.

\section{Acknowledgements}

The authors thank CAPES, CNPq, and FAPERJ for scholarships and financial support, and Jorge L. Silva, A. A. Werle (ICEB-UFOP, Ouro PretoMG, Brazil), T. M. S. da Silva and M. F. Agra (LTF-UFPB, João Pessoa-PB, Brazil) for collection and identification of L. octandra and $\mathrm{O}$. hexasperma, respectively.

\section{References}

1. da Rocha AB, Lopes RM, Schwartsmann G. Natural products in anticancer therapy. Curr Opin Pharmacol 2001;1:364-9.

2. Schwartsmann G, Brondani da Rocha A, Berlinck RG, Jimeno J. Marine organisms as a source of new anticancer agents. Lancet Oncol 2001;2:221-5.

3. Mans DR, da Rocha AB, Schwartsmann G. Anti-cancer drug discovery and development in Brazil: Targeted plant collection as a rational strategy to acquire candidate anti-cancer compounds. Oncologist 2000;5:185-98.

4. Newman DJ, Cragg GM, Snader KM. The influence of natural products upon drug discovery. Nat Prod Rep 2000;17:215-34.

5. Cragg GM, Newman DJ. Plants as a source of anti-cancer agents. J Ethnopharmacol 2005;100:72-9.

6. Daniel JF, Carvalho MG de, Cardoso RS, Agra MF, Eberlin MN. Others flavonoids from Ouratea hexasperma (Ochnaceae). J Braz Chem Soc 2005;16:634-8.

7. Carvalho MG de, Alves CC, Da Silva KG, Eberlin MN, Werle AA. Luxenchalcone, a New Bichalcone and other Constituents from Luxemburgia octandra. J Braz Chem Soc 2004;15:146-9.

8. Carvalho MG de, De Oliveira MCC, Werle AA. Chemical constituents from Luxemburgia nobilis (EICHL). J Braz Chem Soc 2000;11:232-6.

9. Oliveira MC de, Carvalho MG de, Da Silva CJ, Werle AA. New Biflavonoid and other constituents from Luxemburgia nobilis (EICHL). J Braz Chem Soc 2002;13:119-23.

10. Moreira IC, Sobrinho DC, Carvalho MG de, Braz-filho R. Isoflavanone dimmers hexaspermone A, B and C from Ouratea hexasperma. Phytochemistry 1994:35:1567-72.

11. Moreira IC, Carvalho MG de, Bastos ABFO, Braz-Filho R. A flavone dimer from Ouratea hexasperma. Phytochemistry 1999;51:833-8.

12. Velandia JR, Carvalho MG de, Braz-Filho R, Werle AA. Biflavonoids and a Glucopyranoside Derivative from Ouratea semiserrata. Phytochem Anal 2002;13:283-92.

13. Carvalho MG de, Velandia JR, De Oliveira MC, Echevarria A, Braz-Filho R, Grynberg NF. Chemical structure, cytotoxic and antitumour activities of biflavonoids from Brazilian ouratea (Ochnaceae). In: Phytochemical and Pharmacology II of the Series "Recent Progress in Medicinal Plants". Majumdar DK, Govil JN, Singh VK, editors. vol. 8, SCI Tech Publishing LLC: Texas, USA; 2002. p. 77-92.

14. Grynberg NF, Carvalho MG de, Velandia JR, Oliveira MC de, Moreira IC, BrazFilho $R$, et al. DNA topoisomerase inhibitors: Biflavonoids from Ouratea species. Braz J Med Biol Res 2002;15:819-22.

15. Oliveira MC de, Carvalho MG de, Grynberg NF, Brioso PS. A Biflavonoid from Luxemburgia nobilis as inhibitor of DNA topoisomerases. Planta Med 2005;71:5636.

16. Lee KH. Anticancer drug design based on plant-derived natural products. J Biomed Sci 1999;6:236-50.

17. Shi Q, Chen K, Chen X, Brossi A, Verdier-Pinard P, Hamel E, et al. Antitumor agents 183. Synthesis, conformational analysis, and antitubulin activity of allothiocolchicinoids. J Org Chem 1998;63:4018-25.

18. Iwu MM. Biflavanones of garcinia: Pharmacological, and biological activities in plant flavonoids in biologiy and medicine, biochemical, pharmacological, and structure-activity relationships. In: Cody V, Middleton E Jr, Harborne JB, editor. AR Liss, Inc: NY; 1986. p. 485-8.

19. Skehan P, Storeng R, Scudiero D, Monks A, Mcmahon J, Vistica D, et al. New colorimetric cytotoxicity assay for anticancer-drug screening. J Nat Cancer Inst 1990;82:1107-12.

20. Monks NR, FerrazA, Bordgnon SA, Machado KR, Richter MF, da Rocha AB, et al. In vitro cytotoxicity of extracts from Brazilian asteraceae. Pharm Biol 2002;40:494500.

21. Haberlein $\mathrm{H}$, Tschiersch KP, Schafer HL. Flavonoids from Leptospermum scoparium with affinity to the benzodiazepine receptor characterized by structure activity relationships and in vivo studies of a plant extract. Pharmazie 1994;49:91222.

22. Dimmock JR, Elias DW, Beazely MA, Kandepu NM. Bioactivities of chalcones. Curr Med Chem 1999;6:1125-49.

23. Yit CC, Das NP. Cytotoxic effect of butein on human colon adenocarcinoma cell proliferation. Cancer Lett 1994;82:65-72. 